\title{
Aipysurus mosaicus, a new species of egg-eating sea snake (Elapidae: Hydrophiinae), with a redescription of Aipysurus eydouxii (Gray, 1849)
}

\author{
KATE L. SANDERS ${ }^{1}$, ARNE R. RASMUSSEN ${ }^{2}$, JOHAN ELMBERG ${ }^{3}$, MUMPUNI $^{4}$, \\ MICHAEL GUINEA ${ }^{5}$, PETER BLIAS ${ }^{6}$, MICHAEL S.Y. LEE ${ }^{6} \&$ BRYAN G. FRY ${ }^{7}$ \\ ${ }^{1}$ School of Earth and Environmental Sciences, University of Adelaide, South Australia 5000, Australia. \\ E-mail:kate.sanders@adelaide.edu.au
}

${ }^{2}$ The Royal Danish Academy of Fine Arts, Schools of Architecture, Design and Conservation, Esplanaden 34, DK-1263, Copenhagen, Denmark.E-mail: arr@kons.dk

${ }^{3}$ Aquatic Biology and Chemistry, Kristianstad University, SE-29188 Kristianstad, Sweden. E-mail: Johan.Elmberg@hkr.se

${ }^{4}$ Museum Zoologi Bogor, Puslit Biologi-LIPI, Cibinong, Indonesia. E-mail: sancoyomumpuni@yahoo.com

${ }^{5}$ School of Science and Primary Industries, Charles Darwin University, Darwin NT 0909, Australia.

E-mail:Michael.Guinea@cdu.edu.au

${ }^{6}$ Earth Sciences Section, South Australian Museum, North Terrace, Adelaide 5000, Australia. E-mail:Mike.Lee@samuseum.sa.gov.au ${ }^{7}$ School of Biological Sciences, University of Queensland, Brisbane, Australia. E-mail: venomdoc666@gmail.com

\begin{abstract}
We describe a new species of egg-eating sea snake, Aipysurus mosaicus sp. nov., from northern Australia and southern New Guinea. This species was previously considered to be an allopatric population of A. eydouxii, which occurs throughout the Sunda Shelf and in New Guinea. Molecular analyses reveal these two species to be sister lineages with fixed nucleotide substitutions at three independent mitochondrial and nuclear loci, and a deep phylogenetic divergence exceeding that of all other sampled species pairs in Aipysurus. Aipysurus mosaicus sp. nov. is also distinguished from A. eydouxii by morphological characters relating to scalation (e.g. number of ventral scales), colour pattern (e.g. number and shape of transverse body bands), internal soft anatomy (e.g. position of heart in relation to ventral scales), and skeletal morphology (e.g. shape of nasal and caudal neural spines). Additional sampling is needed to clarify the extent of geographic contact between A. eydouxii and the new species in New Guinea where they appear to be sympatric. It is likely that the boundaries between these taxa will be mirrored in other coastal sea snakes with ranges spanning the deep waters of the Timor Trench; discovery of such cryptic species will have important implications for conservation of this highly diverse but relatively poorly studied group of marine vertebrates.
\end{abstract}

Key words: anonymous nuclear, Hydrophiinae, Indo-Australia, marine, mitochondrial, morphology

\section{Introduction}

The viviparous sea snakes (Hydrophiinae: Hydrophiini) are the most species-diverse and probably also the youngest group of fully marine reptiles (Heatwole 1999; Sanders et al. 2010). The 61 species currently recognised mostly occupy shallow-water marine habitats and are distributed throughout the tropical and subtropical Indo-West Pacific (David \& Ineich 1999; Heatwole 1999; Rasmussen et al. 2011). In addition to three semi-aquatic monotypic genera, two well-defined groups of viviparous sea snakes are recognised on the basis of morphological characters (Smith 1926; Voris 1977; Rasmussen 1997, 2002), and molecular sequence data (Lukoschek \& Keogh 2006; Lukoschek et al. 2011). The Hydrophis group is by far the most species rich, with 48 species in 10 genera, many of which are widely distributed. The Aipysurus group contains only ten species in the genera Aipysurus and Emydocephalus, and most are restricted to the Australo-Papuan region.

Aipysurus monophyly is strongly supported by morphological and molecular data (Smith 1926; Voris 1977; Rasmussen 2002; Lukoschek \& Keogh 2006). Smith (1926) described two new species of Aipysurus and so recognised a total of seven species: Aipysurus apraefrontalis Smith, 1926, A. duboisii Bavay, 1869, A. eydouxii (Gray, 
1849), A. foliosquama Smith, 1926, A. fuscus (Tschudi, 1837), A. laevis Lacépède, 1804 and A. tenuis Lönnberg \& Andersson, 1913. Since then only A. pooleorum Smith, 1974 has been added to Aipysurus, first as a subspecies of A. laevis by Smith (1974) and later elevated to full species status without comment (Wells \& Wellington 1983). The latter authors also resurrected A. jukesii (Gray, 1846) from synonymy of A. laevis, but this species has not subsequently been recognised (Cogger 1992; Golay et al. 1993; David \& Ineich 1999; Kharin 2005). Wells (2007) split Aipysurus into six genera, but provided no empirical justification for these classifications and they have not been widely adopted.

Based on current taxonomy, Aipysurus eydouxii is the most extensively distributed Aipysurus species and the only member of the genus confirmed to occur outside of the Australo-Papuan region. It occupies shallow mud- and sand- bottom habitats from northern Australia and New Guinea to Indonesia, Malaysia, the Gulf of Thailand and Vietnam, where it feeds almost exclusively on fish eggs (Limpus 1975; Glodek \& Voris 1982). This unusual diet (shared only with the two Emydocephalus species among sea snakes) has been associated with a secondary reduction of the venom glands, fangs and neurotoxicity ( $\mathrm{Li}$ et al. 2005a, b). Aipysurus eydouxii was first described as Tomogaster eydouxii by Gray (1849) who gave the type locality as 'Indian Ocean'. Later Boulenger (1896) assigned it to Aipysurus and the species has since been placed in this genus. Two specimens collected from Java were given the names Thalassophis anguillaeformis Schmidt, 1852 and T. muraenaeformis Schmidt, 1852 by Schmidt (1852), and another specimen from Java was described as Aipysurus margaritophorus by Bleeker (1858). All of these taxa were later synonymised with A. anguillaeformis by Günther (1864). Krefft (1869) followed Günther in recognising only A. anguillaeformis, which was later synonymised with A. eydouxii by Boulenger (1896). Wall (1909) and Smith (1926) adopted Boulenger's classification of A. eydouxii, which has also been accepted by most recent workers (e.g. Voris 1977; Cogger et al. 1983; Golay et al. 1993; David \& Ineich 1999).

The authors' recent collection of Aipysurus from Java in Indonesia allowed the first comparisons of DNA sequences for what, based on current taxonomy, would be considered Southeast Asian and Australian populations of the species A. eydouxii. Data for three molecular loci showed high levels of divergence between Australian and Asian specimens, and these groups were later found to be morphologically diagnosable from each another and their congeners. On these grounds we here describe the Australian population as a new species, keeping the original name A. eydouxii for the populations distributed chiefly in Asia (Java, Borneo, Peninsular Malaysia, Gulf of Thailand, Cambodia and Vietnam, but also east to New Guinea).

\section{Material and methods}

Molecular analyses. We sampled 11 specimens of Aipysurus eydouxii from Asia (six specimens from the Madura Straits in East Java, Indonesia) and northern Australia (five specimens from the Gulf of Carpentaria), plus an additional 19 sea snakes representing five Aipysurus group species, and one Hydrophis group species (H. caerulescens) to provide an outgroup. Tissues (liver biopsies and tail clippings) and voucher specimens were obtained by the authors during field trips between 2005 and 2010 and as loans from museum collections. All tissues used in this study have accompanying voucher specimens accessioned in museums in Australia and Indonesia. Specimen localities, voucher numbers and GenBank accessions are given in Appendix 1. Standard Proteinase K protocols were used to extract whole genomic DNA and fragments were amplified using HotMaster Taq polymerase reagents (Perkin Elmer), the double-stranded amplification products visualised on $1.5 \%$ agarose gel. Three independent molecular loci were used to assess species boundaries: a composite of three concatenated mitochondrial (mt) fragments, and two nuclear sequences. Mitochondrial genes were $1100 \mathrm{bp}$ of cytb (cytochrome b), $750 \mathrm{bp}$ of ND4 (NADH dehydrogenase subunit 4) and adjacent tRNA-His, tRNA-Ser and tRNA-Leu genes, and 510 bp of 16S rRNA (16S small subunit ribosomal RNA). Nuclear loci were G1888 (402bp) and G1894 (429bp); these are non-coding anonymous markers that were selected from shotgun sequencing (see Bertozzi et al. (2012) for details of laboratory and bioinformatic protocols). Double-stranded sequencing was outsourced to the Australian Genome Research Facility Ltd (AGRF) in Brisbane, Australia. Cytb primers were Forward L14910 (5'- GAC CTG TGA TMT GAA AAA CCA YCG TTG T -3') and Reverse H16064 (5'- CTT TGG TTT ACA AGA ACA ATG CTT TA -3') (Burbrink $e t$ al. 2000). ND4 and adjacent tRNA primers were Forward ND4 (5'-TGA CTA CCA AAA GCT CAT GTA GAA GC-3') and Reverse tRNA-Leu (5'-TAC TTT TACC TTG GAT TTG CAC CA-3') (Arévalo et al. 1994). 16S primers were Forward M1272 (5'-CGC CTG TTT ATC AAA AAC AT-3') and Reverse M1273 (5'-CCG GTC TGA 
ACT CAG ATC ACG T-3') (Kocher et al. 1989). Nuclear primers were Forward G1888 (5'-CAG GGC CTT GCC TTG TGC CA-3') and Reverse G1889 (5'-ACC TCT GCG CAC TAT GAC TCT TGA-3'); and Forward G1894 (5'- ACC CTT TCA GTC ACA GGT CTG CT-3') and Reverse G1895 (5'- GAG CGA AAC AGG GAG TTA TCC AAG C-3'). Annealing temperatures were between 52 and $55^{\circ} \mathrm{C}$ for the mitochondrial markers and $59 \mathrm{C}$ for both nuclear markers.

Sequences were checked for ambiguities, and alignments were assembled from consensus sequences of forward and reverse reads using Geneious Pro v5.1.7 software (Drummond et al. 2010). Because the three anonymous nuclear loci contained sequences with multiple heterozygous sites, nucleotide polymorphisms were assigned to a single allelic copy using the Bayesian approach implemented in PHASE v. 2.1.1 (Stephens et al. 2001; Stephens \& Donnelly 2003). The most probable haplotypes for each individual were used in all further analyses of these loci. Polymorphism and divergence statistics were calculated using DnaSP v5 (Librado \& Rozas 2009) and the Species Delimitation plugin for Geneious Pro (Masters et al. 2011).

Bayesian and parsimony methods were used to reconstruct gene trees for the mitochondrial and nuclear sequences respectively. We opted not to combine the loci to generate a concatenated tree because of the disparity in phylogenetic signal between the mitochondrial alignment and much smaller and less variable nuclear fragments (see Results and Table 1). Although methods are available to construct species trees from multiple gene trees (e.g. Heled \& Drummond 2010), these require a priori assignment of individuals to species and thus are not appropriate for investigating species boundaries. Bayes factors (Kass \& Raftery 1995) were used to assess a three-partition strategy for the mitochondrial data (coding gene by codon position: $1^{\text {st }}+2^{\text {nd }}$ vs $3^{\text {rd }}$; and rRNA) versus a five-partition strategy (each coding gene separately by codon position: $1^{\text {st }}+2^{\text {nd }}$ vs $3^{\text {rd }}$; and rRNA). The three partition strategy was selected (based on Bayes factors and likelihood scores of the two models at stationarity) and partitions were assigned best-fit models of nucleotide evolution as measured by the Akaike Information Criterion (AIC) in MrModeltest v. 2.3 (Nylander 2004) and PAUP (Swofford 2002): $\mathrm{mt}$ protein-coding $1^{\text {st }}+2^{\text {nd }}$ codon positions (GTRig), mt protein-coding $3^{\text {rd }}$ positions (GTRig), rRNA (GTRig). MrBayes v.3.1.2 (Ronquist \& Huelsenbeck 2003) was used to reconstruct the concatenated mitochondrial phylogeny with values for model parameters unlinked, i.e. allowed to vary independently across partitions. MCMC analyses were repeated multiple times using different starting seeds and four chains each. Because upwardly biased branch rate inference can occur for some datasets in MrBayes (Brown et al. 2010), we additionally checked the branch lengths output from MrBayes against maximum likelihood branch lengths estimated using GARLI (Genetic Algorithm for Rapid Likelihood Inference: Zwickl 2006). The MrBayes final analysis was run for 6,000,000 generations and sampled every 1000 generations. The first $30 \%$ of sampled trees were excluded as burn-in. Convergence was assessed by examining effective sample sizes (ESS values) and likelihood plots through time in TRACER v. 1.4.1 (Rambaut \& Drummond 2007), and by comparing the split posterior probabilities from four different runs in MrBayes. The two nuclear loci had few variable sites (Table 1), thus providing low power for model-based (i.e. likelihood or Bayesian) tree inference. For this reason, heuristic parsimony searches implemented in the dnapars program in Felsenstein's (Felsenstein 1989) PHYLIP package (http://evolution.genetics.washington.edu) were performed using 10,000 replicates to find the most parsimonious tree(s) for these loci. All analyses used Hydrophis caerulescens as an outgroup because there is strong molecular (Lukoschek \& Keogh 2006; Sanders et al. 2008) and morphological (Voris 1977; Rasmussen 1997) evidence that the Aipysurus group and the Hydrophis groups are reciprocally monophyletic.

Morphological analyses. Measurements and scale counts follow Smith (1926) with the modification that scale rows were counted directly around the body (see Thomas 1976). The absolute position of the posterior tip of the heart and the anterior tip of the liver were determined in relation to the count of the adjacent ventral scales (VS). The relative positions of the posterior tip of the heart and the anterior tip of the liver are expressed as the percentage of the number (counted from head to rear) of the underlying ventral scale (\%VS-heart and \%VS-liver). These characters have proven informative in previous systematic studies of sea snakes (e. g. Rasmussen 1989, 1993). Body length was measured from snout to vent and tail length from vent to tip of the tail. Sub-adult specimens were not included in morphological analyses; adults were identified by large, non-flaccid testes in males and thickened oviducts and/or visible vitellogenic follicles in females. Specimens used in morphological analyses span the known geographic range of Aipysurus eydouxii in the Southeast Asian and Australian regions and are listed in Appendix 2. Museum abbreviations follow Leviton et al. (1985): Zoological Museum of Amsterdam (AMS); British Museum of Natural History (BMNH); Queensland Museum, Brisbane, Australia (QM); Queensland Museum, Brisbane, Australia (QM); South Australian Museum, Adelaide, Australia (SAMA); Museum of Zoology, Bogor, 
Indonesia (MZB); Museum of Natural History, Paris, France (MNHN); Museum of Zoology, Western Australian Museum, Perth, Australia (WAM); Raffles Museum of Biodiversity Research, Singapore (RMBR); University of Copenhagen, Denmark (ZMUC); Zoological Museum of Hamburg, Germany (ZMH). Tissues without vouchers are numbered using MG (collected by Michael Guinea) and BGF (collected by Bryan Fry) prefixes.

To identify distinguishing skeletal characters that were not size-related, micro-CT scanning of one smaller and one larger individual of Aipysurus eydouxii from both Asia and Australia was performed. All specimens were scanned on a Skyscan 1076 in-vivo X-ray microtomograph at Adelaide Microscopy with the following general settings: resolution $18 \mu \mathrm{m}$, rotation step 0.6 degrees, time $295 \mathrm{msec}$, filter nil. The following settings were optimised for each specimen: R23493 - voltage $74 \mathrm{kV}$, current $133 \mu \mathrm{A}$; R65222 - voltage $65 \mathrm{kV}$, current $129 \mu \mathrm{A}$; MZB Ophi 4184 - voltage $65 \mathrm{kV}$, current $139 \mu \mathrm{A}$. All reconstructions were performed with Skyscan software (www.skyscan.be/ products/downloads.htm). The conversion to cross sections was done using NRecon; images were then manipulated and 3D models created using CTAn. The 3D models were viewed and still images made using CTVol. Scale was obtained by measuring the x-ray images in Skyscan's Tview software as well as measuring some dimensions in the cross sectional images with CTAn.

\section{Results}

Molecular analyses. The final data matrix comprised 30 individuals and 3323 base pairs and is $80 \%$ complete by locus (30 sequences missing from a possible total of 150). All sequences are deposited at GenBank (Appendix 1). Translation of the protein-coding genes cytb and ND4 did not reveal frameshifts, unexpected stop codons or indels. The concatenated $\mathrm{mt}$ alignment contained 593 polymorphic sites, whereas the phased nuclear loci G1888 and G1894 contained 10 and 13 polymorphic sites, respectively.

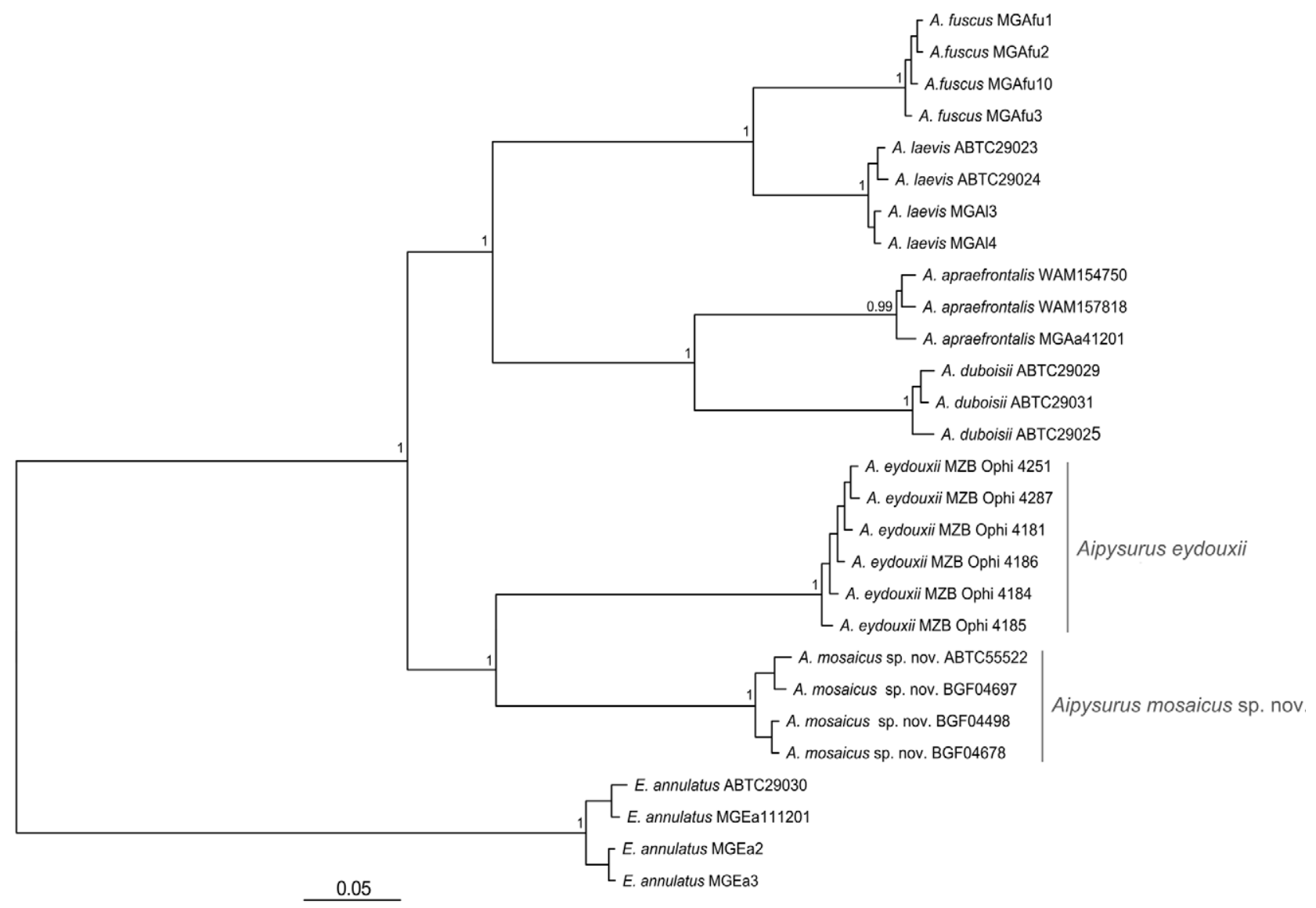

FIGURE 1. MrBayes all compatible consensus of 4000 post burn-in trees for the Aipysurus and Emydocephalus specimens sampled in this study based on the concatenated mitochondrial data (Hydrophis caerulescens outgroup not shown). Scale bar indicates the number of nucleotide substitutions per site. Node support values (posterior probabilities) above 0.95 are shown. 


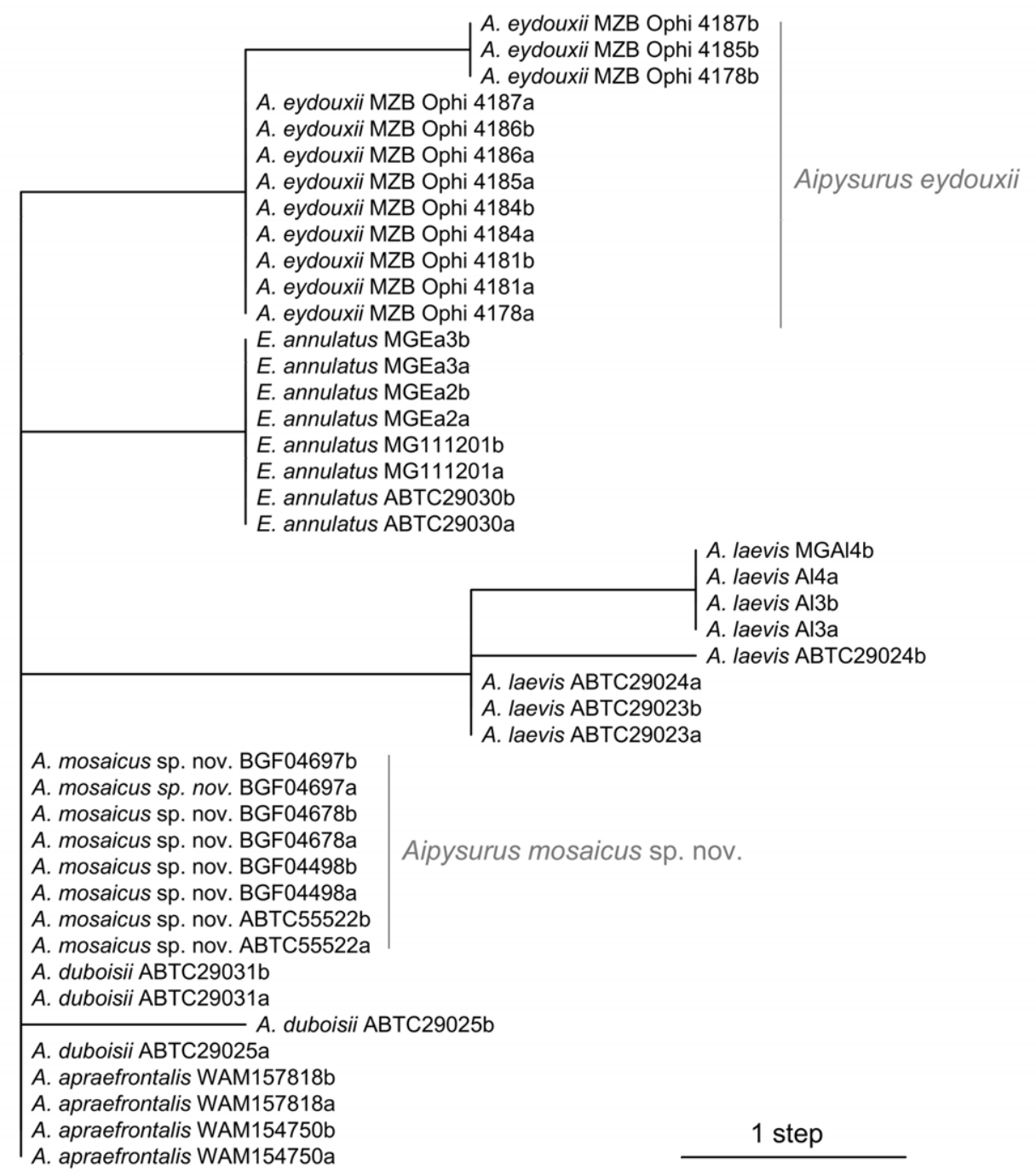

FIGURE 2. The single most parsimonious tree for phased haplotypes of the nuclear G1894 fragment. Scale bar indicates branch lengths corresponding to 1 step.

Bayesian mitochondrial analyses yielded effective sample sizes (ESS values) above 1000 for all parameters and branch lengths that were similar to those estimated using GARLI. Aipysurus eydouxii from Asia and Australia were recovered as reciprocally monophyletic sister groups with a posterior probability of 1.0 (Fig. 1). These lineages were strongly resolved as sister to a clade containing all remaining sampled Aipysurus: $((A$. laevis + A. fuscus)(A. apraefrontalis + A. duboisii)) (node posterior probabilities from 0.99 to 1.0). Mitochondrial pairwise distances (HKY) were 5.6\% between A. eydouxii from Asia and Australia, and ranged from 2.6\% to 7.2\% among other sampled Aipysurus species. 


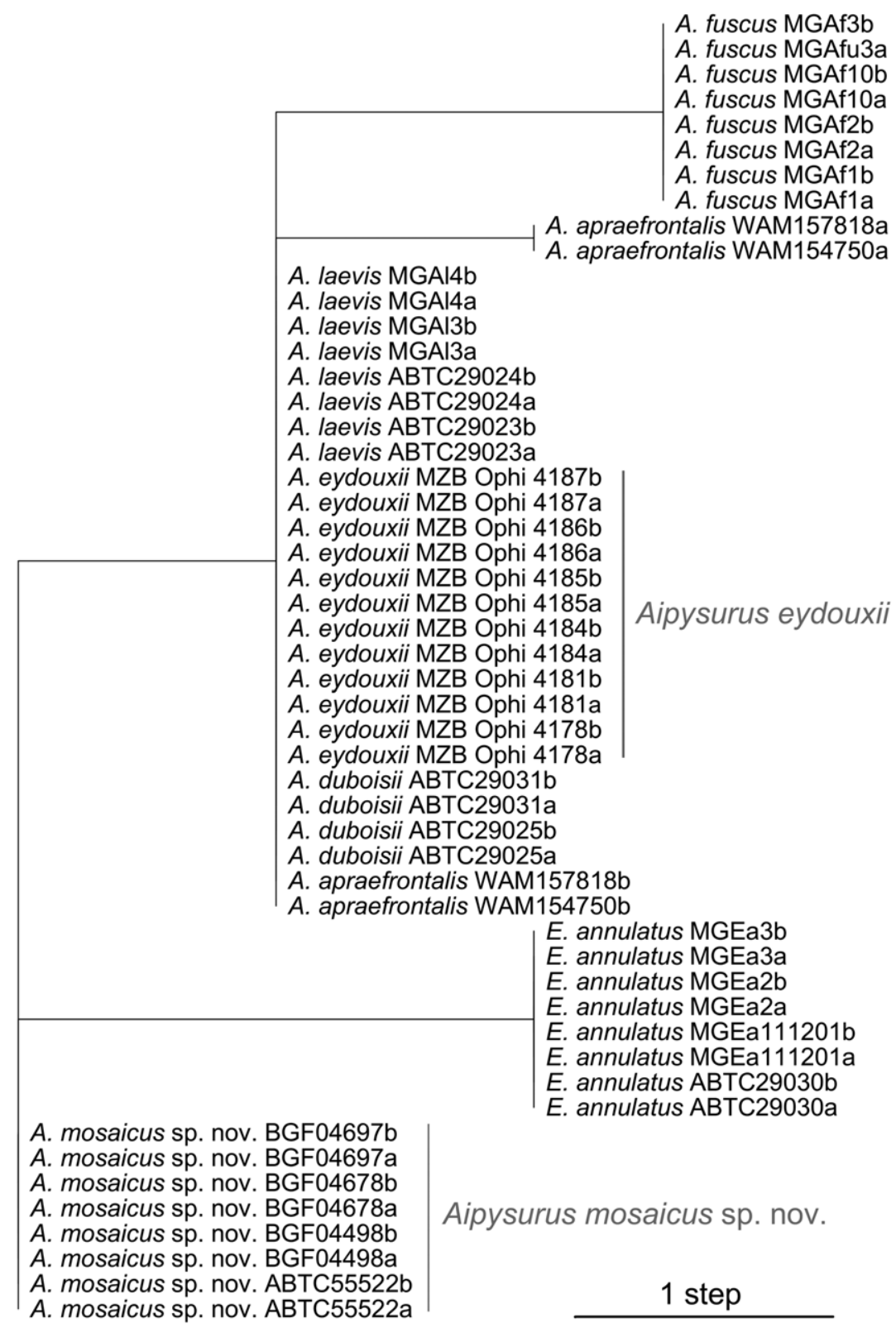

FIGURE 3. The single most parsimonious tree for phased haplotypes of the nuclear G1888 fragment. Scale bar indicates branch lengths corresponding to 1 step.

Parsimony searches yielded a single most parsimonious tree for each nuclear fragment (Figs. 2 and 3). The Aipysurus eydouxii samples from Australia and from Asia did not share any haplotypes for each of the three loci (Table 1). There were 113 fixed differences between Asian and Australian A. eydouxii in the mt alignment. The nuclear G1894 locus showed one fixed substitution between Asian and Australian A. eydouxii; Asian A. eydouxii had two unique haplotypes for this locus, whereas Australian A. eydouxii had a single haplotype that was shared 
with two other Aipysurus species (A. duboisii and A. apraefrontalis) (Fig. 2). For G1888, there was one fixed difference between Asian and Australian A. eydouxii; Australian A. eydouxii had one unique haploytpe, and Asian A.eydouxii had a single haplotype, which it shared with A. duboisii, A. apraefrontalis and A. laevis (Fig. 3).

TABLE 1. Molecular loci used in the study, including length, best-fit substitution model, number of polymorphic sites, and number of fixed substitutions between Aipysurus mosaicus sp. nov. and A. eydouxii.

\begin{tabular}{llllllc}
\hline Locus & Marker type & $\begin{array}{l}\text { Size } \\
(\mathrm{bp})\end{array}$ & Model & \# specimens & $\begin{array}{l}\text { Total polymor- } \\
\text { phic sites }(S)\end{array}$ & $\begin{array}{l}\text { Fixed substitutions between } \\
\text { A. eydouxii and A. mosaicus } \\
\text { sp. nov. }\end{array}$ \\
\hline $\begin{array}{l}\text { concatenated cytb, } \\
\text { ND4, 16S }\end{array}$ & mitochondrial & 2483 & GTR+i+g & 30 & 593 & 113 \\
G1894 & $\begin{array}{l}\text { anonymous } \\
\text { nuclear } \\
\text { anonymous } \\
\text { nuclear }\end{array}$ & 409 & HKY & 23 & 13 & 1 \\
\hline
\end{tabular}

Morphology. The morphological analysis revealed several substantial and significant differences between Aipysurus eydouxii specimens from Australia and Asia (Table 2), despite the fairly limited sample size. One character, the number of body bands, showed no overlap (and large differences) between Asian and Australian individuals, irrespective of sex, thus provides a ready diagnostic character (Figs. 4a, b). Sexual dimorphism was evident in both geographical groups, with females generally having more ventral and fewer subcaudal scales, and fewer tail bands than males. The cranial and caudal skeletal anatomy of A. eydouxii of Asian versus Australian origin also exhibited clear differences in the premaxilla, maxilla, nasal, frontoparietal suture and caudal vertebrae (Fig. 5; see discussion below). These differences are unlikely to be ontogenetic, because they were consistent across both small and large individuals. Our external and internal morphological data were in good agreement with the published data. We found only one outlying value in the literature: Cogger's (1975) ventral scale count is three less than our minimum count for A. eydouxii; however, it is not clear whether Cogger's specimens belong to Asian or Australian populations of this taxon.

Molecular, and external and internal morphological data thus support splitting Aipysurus eydouxii into two distinct species-one primarily Asian and one primarily Australian. Below, we formally describe the new species, and describe the known variation within the two species originating from the taxon formerly known as A. eydouxii.

Aipysurus mosaicus sp. nov.

Figs. 1-3, 4a, 5a-c, 6a-c

Aipysurus eydouxii (Gray, 1849) (part): Smith (1926) (part); MacPherson (1933); Cogger (1975); Limpus (1975); Minton (1975) (part); Reidfield et al. (1978); Cogger et al. (1983) (part); Cogger (1992); Golay et al. (1993) (part); Heatwole \& Cogger (1994); Greer (1997); Porter et al. (1997); David \& Ineich (1999) (part); Heatwole (1999); Ward (2000); Fry et al. (2001); Li et al. (2005a, b); Lukoschek \& Keogh (2006); Cogger (2007).

Tomogaster eydouxii Gray, 1849 (specimens collected from Java and therefore not referable to A. mosaicus): Wells (2007).

Holotype. SAMA R65222. A small adult male collected in the Gulf of Carpentaria near Weipa, Australia, in October 2000 by B.F. Fry. Tail tissue stored in ethanol in the ABTC-SAM.

Paratype. SAMA R23493. An adult female collected in the Gulf of Carpentaria, Australia. Tissue stored frozen in the ABTC-SAM.

Referred specimens. An additional 26 specimens ( 9 adult males, 17 adult females), see Appendix 2 for details. 

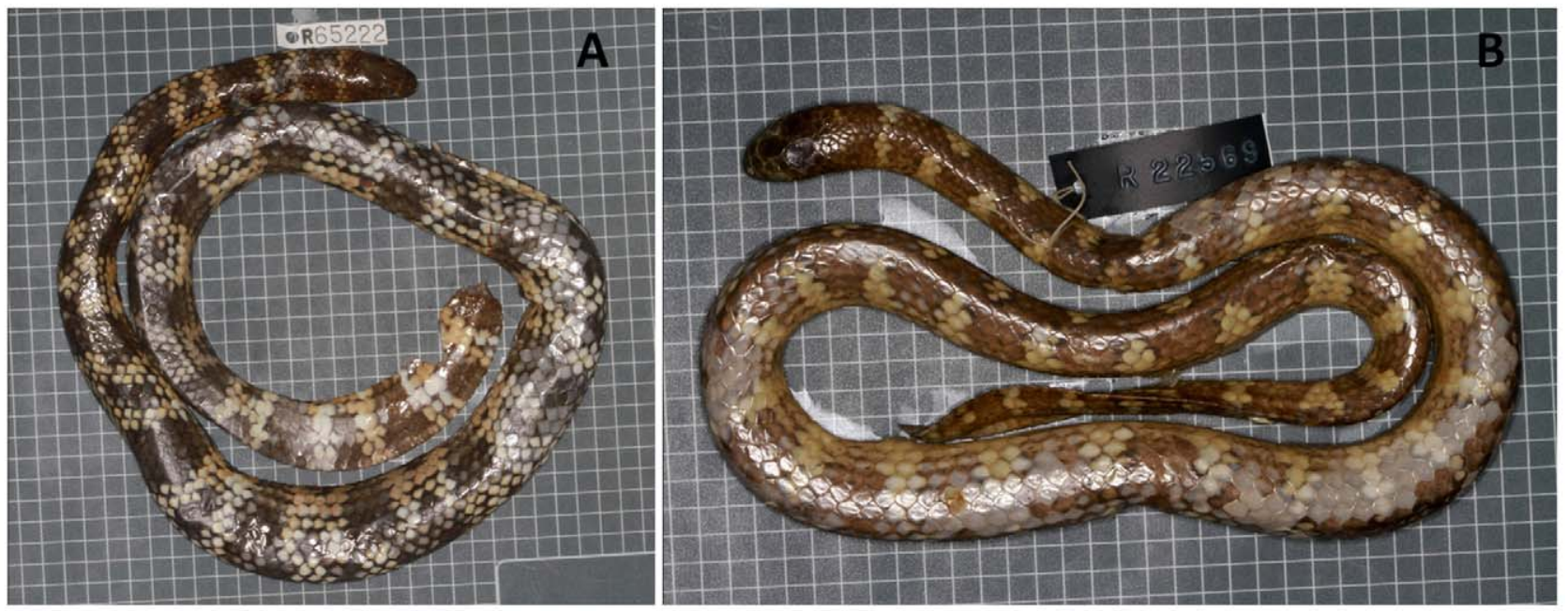

FIGURE 4. Full body photographs of A) the holotype of Aipysurus mosaicus sp. nov. from northern Australia (SAMA R65222) and B) A. eydouxii from Singapore (SAMA R22569). Grid scale represents $1 \mathrm{x} 1 \mathrm{~cm}$. Note that A. mosaicus has fewer bands on the body and tail and that these are less distinct.
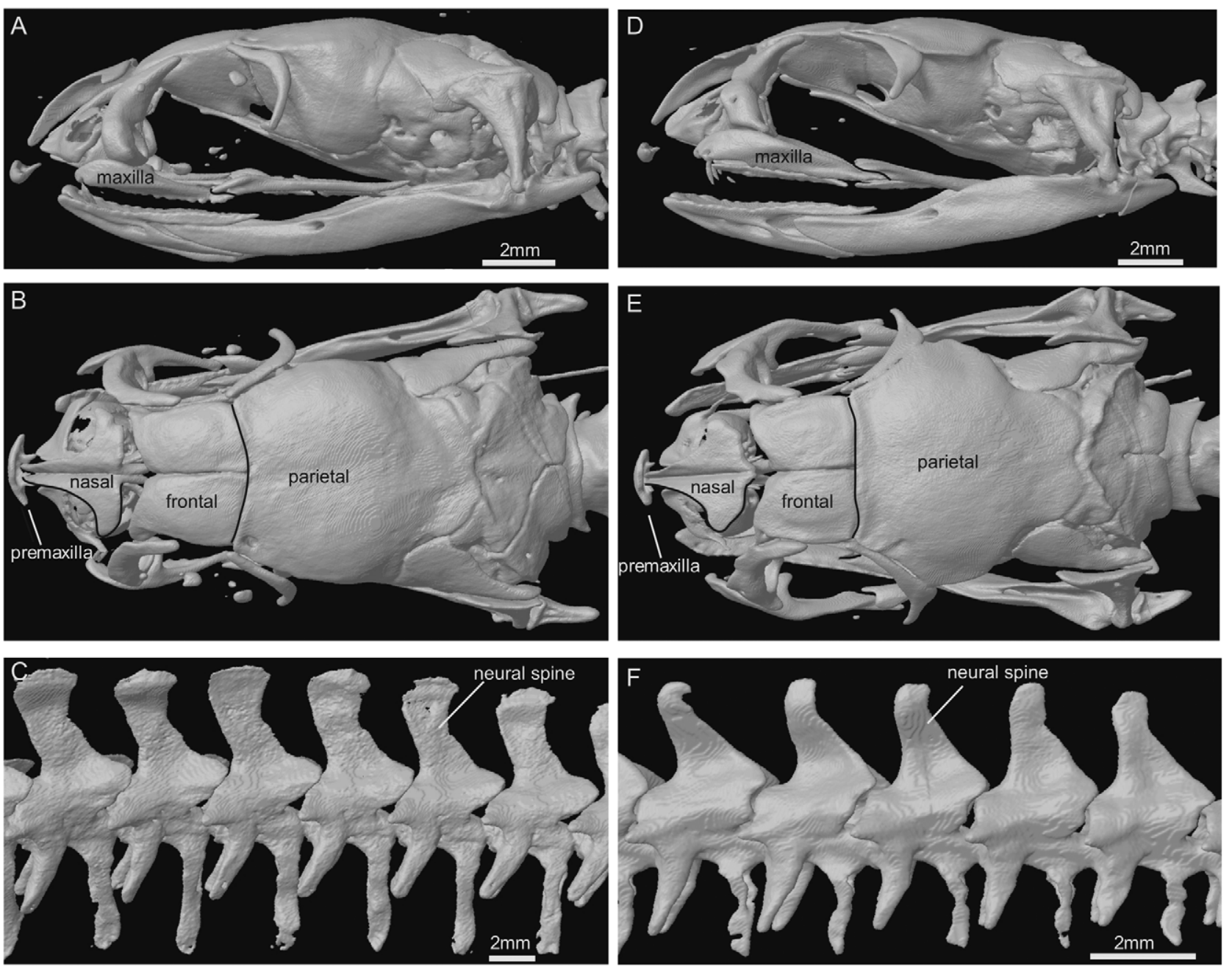

FIGURE 5. Micro-CT images of Aipysurus mosaicus sp. nov. from (A) left lateral and (B) dorsal view of skull, and (C) left lateral view of mid-caudal vertebrae; and Aipysurus eydouxii from (D) left lateral and (E) dorsal view of skull, and (F) left lateral view of mid-caudal vertebrae. Note the differences in the morphology of the premaxilla, maxilla, nasal, frontoparietal suture, and neural spine; see text for fuller discussion. Specimens illustrated are as follows: (A, B) SAMA R65222 holotype, (C) SAMA R23493 paratype, (D, E) MZB Ophi 4184, (F) SAMA R22569. 

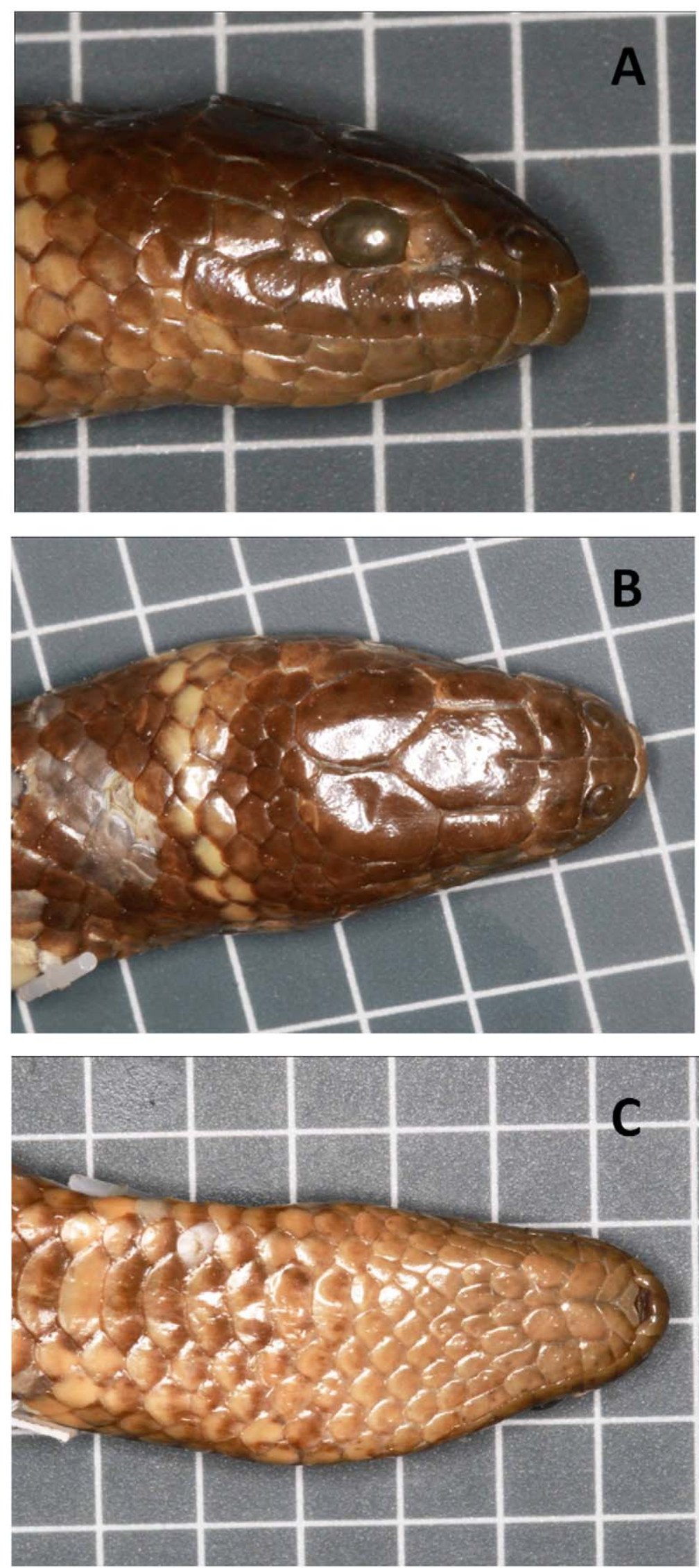

FIGURE 6. A) Right lateral, B) dorsal, and C) ventral photographs of the head of the holotype of Aipysurus mosaicus sp. nov. (SAMA R65222). Grid scale represents 1 x $1 \mathrm{~cm}$. 
TABLE 2. Mean, range, standard deviation, and t-tests of morphological characters comparing Asian (Aipysurus eydouxii) and Australian (A. mosaicus sp. nov.) specimens. Australian data and t-tests include counts from holotype $\left({ }^{\mathrm{H}}\right)$ and paratype $\left({ }^{\mathrm{P}}\right)$ when available. T-test probabilities are two-tailed, with significant contrasts given in bold type. See Methods for explanation of characters. Note that sample sizes for some characters differ from the gross sample size per origin and sex.

\begin{tabular}{|c|c|c|c|}
\hline \multirow[b]{2}{*}{ Character } & \multicolumn{3}{|l|}{ Males } \\
\hline & Asian $(\mathrm{N}=19)($ A. eydouxii $)$ & $\begin{array}{l}\text { Australian }(\mathrm{N}=10) \\
(\text { A. mosaicus } \mathbf{s p .} \text { nov. })\end{array}$ & t-test \\
\hline Scale rows neck & $16.17(15-17, \mathrm{SD}=0.99, \mathrm{~N}=18)$ & $16.90\left(16-17, \mathrm{SD}=0.32, \mathrm{~N}=10^{\mathrm{H}}\right)$ & $\mathrm{P}=0.03, \mathrm{t}=-2.27$ \\
\hline Scale rows body & $16.95(16-17, \mathrm{SD}=0.24, \mathrm{~N}=18)$ & $17.00\left(\mathrm{SD}=0, \mathrm{~N}=10^{\mathrm{H}}\right)$ & $\mathrm{P}=0.47, \mathrm{t}=-0.74$ \\
\hline $\begin{array}{l}\text { Scale rows } 10 \text { ventrals } \\
\text { anterior to vent }\end{array}$ & $15.00(\mathrm{SD}=0, \mathrm{~N}=18)$ & $14.80\left(13-17, \mathrm{SD}=1.14, \mathrm{~N}=10^{\mathrm{H}}\right)$ & $P=0.46, t=0.76$ \\
\hline Scale rows at mid-tail & $8.55(7-10, \mathrm{SD}=1.13, \mathrm{~N}=11)$ & $8.88(8-9, \mathrm{SD}=0.35, \mathrm{~N}=8)$ & $\mathrm{P}=0.44, \mathrm{t}=-0.79$ \\
\hline Body bands & $34.61(30-42, \mathrm{SD}=3.35, \mathrm{~N}=18)$ & $19.25\left(17-22, \mathrm{SD}=1.67, \mathrm{~N}=8^{\mathrm{H}}\right)$ & $\mathrm{P}<0.001, \mathrm{t}=12.22$ \\
\hline Tail bands & $8.67(7-11, \mathrm{SD}=0.97, \mathrm{~N}=18)$ & $5.50\left(5-7, \mathrm{SD}=0.76, \mathrm{~N}=8^{\mathrm{H}}\right)$ & $\mathrm{P}<0.001, \mathrm{t}=8.16$ \\
\hline Ventrals & $138.17(127-143, \mathrm{SD}=3.54, \mathrm{~N}=18)$ & $144.20\left(140-147, \mathrm{SD}=2.28, \mathrm{~N}=10^{\mathrm{H}}\right)$ & $\mathrm{P}<0.001, \mathrm{t}=-4.89$ \\
\hline Subcaudals & $30.89(27-34, \mathrm{SD}=1.67, \mathrm{~N}=19)$ & $33.67(28-38, \mathrm{SD}=3.35, \mathrm{~N}=9)$ & $\mathrm{P}<0.01, \mathrm{t}=-2.95$ \\
\hline Heart position & $51.75(47-56, \mathrm{SD}=2.62, \mathrm{~N}=16)$ & $47.50(44-51, \mathrm{SD}=2.45, \mathrm{~N}=8)$ & $\mathrm{P}<0.001, \mathrm{t}=3.82$ \\
\hline $\begin{array}{l}\text { Relative heart position } \\
(\%)\end{array}$ & $\begin{array}{l}37.50(34.53-40.00, \mathrm{SD}=1.66 \\
\mathrm{N}=16)\end{array}$ & $33.02(30.77-35.21, \mathrm{SD}=1.79, \mathrm{~N}=8)$ & $\mathrm{P}<0.001, \mathrm{t}=6.08$ \\
\hline Liver position & $54.38(50-58, \mathrm{SD}=2.57, \mathrm{~N}=13)$ & $49.88(47-53, \mathrm{SD}=2.17, \mathrm{~N}=8)$ & $\mathrm{P}<0.001, \mathrm{t}=4.13$ \\
\hline \multirow[t]{3}{*}{$\begin{array}{l}\text { Relative liver position } \\
(\%)\end{array}$} & $\begin{array}{l}39.55(35.97-42.22, \mathrm{SD}=1.69 \\
\mathrm{N}=13)\end{array}$ & $34.67(32.87-36.62, \mathrm{SD}=1.62, \mathrm{~N}=8)$ & $\mathrm{P}<0.001, \mathrm{t}=6.53$ \\
\hline & Females & & \\
\hline & Asian $(\mathrm{N}=18)($ A. eydouxii $)$ & Australian $(\mathrm{N}=18)($ A. mosaicus $)$ & t-test \\
\hline Scale rows neck & $16.83(15-17, \mathrm{SD}=0.51, \mathrm{~N}=18)$ & $16.94\left(16-17, \mathrm{SD}=0.24, \mathrm{~N}=18^{\mathrm{P}}\right)$ & $\mathrm{P}=0.41, \mathrm{t}=-0.83$ \\
\hline Scale rows body & $17.00(\mathrm{SD}=0, \mathrm{~N}=18)$ & $17.00\left(\mathrm{SD}=0, \mathrm{~N}=18^{\mathrm{P}}\right)$ & $\mathrm{P}=1.00$ \\
\hline Scale rows vent & $14.9(13-15, \mathrm{SD}=0.47, \mathrm{~N}=18)$ & $14.89\left(13-17, \mathrm{SD}=1.02, \mathrm{~N}=18^{\mathrm{P}}\right)$ & $\mathrm{P}=1.00, \mathrm{t}=0.001$ \\
\hline Scale rows tail & $8.62(7-10, \mathrm{SD}=1.06, \mathrm{~N}=8)$ & $9.00(\mathrm{SD}=0, \mathrm{~N}=14)$ & $P=0.19, t=-1.86$ \\
\hline Body bands & $36.12(29-45, \mathrm{SD}=3.72, \mathrm{~N}=17)$ & $18.25\left(15-21, \mathrm{SD}=1.88, \mathrm{~N}=16^{\mathrm{P}}\right)$ & $\mathrm{P}<0.001, \mathrm{t}=17.55$ \\
\hline Tail bands & $7.00(4-10, \mathrm{SD}=1.24, \mathrm{~N}=18)$ & $4.83\left(4-6, \mathrm{SD}=0.72, \mathrm{~N}=12^{\mathrm{P}}\right)$ & $\mathrm{P}<0.001, \mathrm{t}=6.06$ \\
\hline Ventrals & $142.17(136-149, \mathrm{SD}=3.26, \mathrm{~N}=18)$ & $147.50\left(140-154, \mathrm{SD}=4.32, \mathrm{~N}=18^{\mathrm{P}}\right)$ & $\mathrm{P}<0.001, \mathrm{t}=-4.18$ \\
\hline Subcaudals & $25.00(21-27, \mathrm{SD}=1.64, \mathrm{~N}=18)$ & $28.88\left(25-33, \mathrm{SD}=2.20, \mathrm{~N}=17^{\mathrm{P}}\right)$ & $\mathrm{P}<0.001, \mathrm{t}=-5.88$ \\
\hline Heart position & $51.31(47-55, \mathrm{SD}=2.72, \mathrm{~N}=16)$ & $48.21(45-52, \mathrm{SD}=2.29, \mathrm{~N}=14)$ & $\mathrm{P}<0.005, \mathrm{t}=3.38$ \\
\hline $\begin{array}{l}\text { Relative heart position } \\
(\%)\end{array}$ & $\begin{array}{l}36.10(33.10-39.42, \mathrm{SD}=1.94 \\
\mathrm{N}=16)\end{array}$ & $\begin{array}{l}32.67(30.00-35.71, \mathrm{SD}=1.60 \\
\mathrm{N}=14)\end{array}$ & $\mathrm{P}<0.001, \mathrm{t}=5.34$ \\
\hline Liver position & $54.50(49-60, \mathrm{SD}=2.93, \mathrm{~N}=14)$ & $50.64(47-54, \mathrm{SD}=2.47, \mathrm{~N}=14)$ & $\mathrm{P}<0.005, \mathrm{t}=3.77$ \\
\hline $\begin{array}{l}\text { Relative liver position } \\
(\%)\end{array}$ & $\begin{array}{l}38.23(34.51-41.67, \mathrm{SD}=2.08 \\
\mathrm{N}=14)\end{array}$ & $\begin{array}{l}34.31(32.00-36.73, \mathrm{SD}=1.68 \\
\mathrm{N}=14)\end{array}$ & $\mathrm{P}<0.001, \mathrm{t}=5.45$ \\
\hline
\end{tabular}

Generic assignment. Aipysurus mosaicus has a combination of characters (see type description and variation below) that place it in the genus Aipysurus as defined by Smith (1926: 13): "Maxillary bone as long as or longer than the ectopterygoid, extending forwards beyond the palatine; poison-fangs followed after an interval by from 5 to 11 teeth. Nostrils superior, nasal shields in contact; head-shields regular or broken up; scales imbricate in regular rows, 17-25; ventrals large, one-third to half the breadth of the body, a median keel usually present at least in the posterior part of the body."

Diagnosis. Aipysurus mosaicus is distinct from seven of the eight species (except A. eydouxii) of Aipysurus using external characters. Aipysurus apraefrontalis and A. foliosquama have ventrals with a deep median notch on the posterior edge, A. mosaicus has ventrals lacking a median notch. Aipysurus tenuis has more than 170 ventrals, 
A. mosaicus has 140-154. Aipysurus duboisii, A. fuscus, A. laevis, and A. pooleorum have more than 17 scale rows around midbody and at least some of the head shields are usually broken up into smaller plates, A. mosaicus has 17 scale rows around body and head shields that are normally symmetrical and not broken up.

Aipysurus mosaicus is clearly distinct from A. eydouxii in a number of external and internal characters. Aipysurus eydouxii has 29 or more bands on body, A. mosaicus has 22 body bands or fewer. In our sample, the following characters differ significantly between A. eydouxii and A. mosaicus when compared intrasexually: number of body bands, tail bands, ventrals, subcaudals, as well as heart and liver positions (absolute and relative) (Table 2). Compared to A. eydouxii, A. mosaicus has a larger premaxilla, a smaller maxilla, a cresent-shaped (rather than triangular) nasal, an anteriorly concave (rather than straight) frontoparietal suture, and dorsally-expanded caudal neural spines (Fig. 5).

Description of holotype. Male. Snout-vent length $46.3 \mathrm{~cm}$, tail $8.6 \mathrm{~cm}$. One pre- and two postoculars on both sides. Six supralabials and six infralabials on both sides. First and second supralabials in contact with nasal. Second and third supralabials in contact with preocular on right side, second, third and fourth on left side. Fourth and fifth supralabial in contact with eye. Two anterior temporals on both sides. Sublinguals are well-developed and in contact with one another. First, second, third and fourth infralabials in contact with anterior pair of sublinguals. Fourth infralabial touching posterior pair of sublinguals. Seventeen scale rows on neck, 17 scale rows on body, 15 scale rows ten ventrals before vent. Ventrals 144, distinct throughout, about three to four times as broad as adjacent scales. Preanals enlarged and divided into paired scales. Subcaudals cannot be counted reliably due to a tail biopsy but probably number between 29 and 32. Head dark brown above and below. Body dark brown above, paler below. Twenty-one irregular brown bands on body and five on tail.

Description of paratype (R23493). Female. Snout-vent length $73.0 \mathrm{~cm}$, tail $11.5 \mathrm{~cm}$. One pre- and two postoculars on both sides. Six supralabials and six infralabials on both sides. First and second supralabials in contact with nasal. Second, third and fourth supralabials in contact with preocular on both sides. Fourth and fifth supralabial in contact with eye. Two anterior temporals on both sides. Sublinguals are well-developed and in contact with one another. First, second and third infralabial in contact with anterior pair of sublinguals. Third and fourth infralabial touching posterior pair of sublinguals. Seventeen scale rows on neck, 17 scale rows on body, 13 scale rows ten ventrals before vent. Ventrals 154, distinct throughout, about three to four times as broad as adjacent scales. Preanals enlarged and split up into two scales. Twenty-nine subcaudals. Head dark brown above and below. Body dark brown above, lighter below. Seventeen white/cream irregular brown bands on body and five on tail.

Variation in Aipysurus mosaicus sp. nov. The following description refers to all 28 A. mosaicus specimens examined (10 adult males, 18 adult females), including the holotype and paratype: see Table 2 and Appendix 2.

External morphological characters. One pre- and two postoculars on both sides in 25 specimens, 1-2/1-1 in two specimens, and 1-3/1-2 in one specimen. Six/six supralabials in 26 specimens, $7 / 6$ in two specimens. First and second supralabials in contact with nasal in 26 specimens, first, second and third in two specimens. Second, third and fourth supralabial in contact with preocular in 22 specimens, second and third in six specimens. Fourth supralabial in contact with eye in 22 specimens, third and fourth in one specimen, fourth and fifth in four specimens, and third, fourth and fifth in one specimen. Two anterior temporals on both sides in 22 specimens, $1 / 1$ in one specimen, 1/2 in one specimen, $2 / 3$ in three specimens and $3 / 3$ in one specimen. Six infralabials on both sides in 26 specimens, $7 / 7$ in two specimens. Sublinguals well-developed and in contact with one another in all specimens. First, second and third infralabial in contact with anterior pair of sublinguals in 24 specimens, first through fourth in four specimens. Third and fourth infralabials touching posterior pair of sublinguals in 22 specimens, only the fourth in six specimens. Sixteen to seventeen scale rows on neck in males, 16-17 in females, 17 scale rows on body in males, 17 in females. Thirteen to seventeen scale rows ten ventrals before vent in males, 13-17 in females. Ventrals 140-147 in males, 140-154 in females, distinct throughout, about three to four times as broad as adjacent scales. Preanals enlarged and split up into two scales. Subcaudals 28-38 in males, 25-33 in females. Snout-vent length of largest male $68 \mathrm{~cm}$, tail $14 \mathrm{~cm}$; largest female $95 \mathrm{~cm}$, tail $15 \mathrm{~cm}$.

Internal morphological characters. Tip of heart extending to ventral scale number 44-51 in males, 45-52 in females. \%VS-heart $30.8-35.2 \%$ in males, $30.0-35.7 \%$ in females. Anterior end of liver situated at ventral scale number $47-53$ in males, $47-54$ in females. \%VS-liver $32.9-36.6 \%$ in males, $32.0-36.7 \%$ in females. Heart and liver separated by $1-4$ ventral scales in males, $1-5$ in females.

Colouration. Head dark brown above and below. Body usually cream, salmon or yellowish with brown to olive green irregular cross-bands. Bands are often incomplete with some forming staggered half-bands on either 
side of the body. Number of bands on body 17-22 in males and 15-21 in females (when distinct enough to be counted). Number of bands on tail 5-7 in males and 4-6 in females.

Distribution. The new species is found along the coasts of northern Australia and southern New Guinea. We have examined specimens (Appendix 2) belonging to this species from the following localities in northern and north-eastern Australia: Coburg Peninsula (Arafura Sea), the Gulf of Carpentaria (southeast and northeast areas), Thursday Island (Torres Strait), Townsville (northeast Queensland), and Swain Reefs and Shoal Water Bay (southeast Queensland). A single specimen was examined from Kaap Valsch (= Tanjung Vals) on the south coast of West Papua. Limpus (1975) reports this species as breeding as far south as $26^{\circ} \mathrm{S}$ in subtropical Queensland.

Etymology. Named from the Latin mosaicus in reference to the mosaic-like pattern of dark and light scales arranged in irregularly staggered cross-bands. We suggest the common name mosaic sea snake for this species.

Natural history. All collection records suggest that Aipysurus mosaicus (mentioned as A. eydouxii) inhabits offshore waters, estuaries and tidal rivers, where it is associated with soft sand and mud bottom substrates. Most records are from depths between $2 \mathrm{~m}$ (Heatwole 1975) and 22m (Redfield et al. 1978) and there are no records from waters exceeding 50m. Limpus (1975) examined the guts of $>100$ A. mosaicus specimens from southern Queensland; 38\% contained diet items, all of which were clumps of benthic fish eggs. A similarly specialist diet of fish eggs (and occasionally squid and cuttlefish) was reported for A. eydouxii in Malaysia (Voris 1966; Glodek \& Voris 1982). In northern Australia, females of A. mosaicus are gravid between May and August but not in October (Fry et al. 2001).

\section{Aipysurus eydouxii (Gray, 1849)}

Aipysurus eydouxii (Gray, 1849); Boulenger (1896); Flower (1899); Wall (1909); Smith (1926) (part); Smith (1943); Taylor (1965); Lim \& Sawai (1975); Lemen \& Voris (1981); Kharin (1981); Glodek \& Voris (1982); McCarthy \& Warrell (1991); Stuebing (1991); Golay et al. (1993) (part); Murphy et al. (1999); David \& Ineich (1999) (part); Kharin \& Hallermann (2009); Rasmussen et al. (2011)

Tomogaster eydouxii Gray, 1849

Thalassophis anguillaeformis Schmidt, 1852

Thalassophis muraenaeformis Schmidt, 1852

Aipysurus anguillaeformis (Schmidt, 1852): Gunther (1864); Krefft (1869)

Aipysurus margaritophorus Bleeker, 1858

Variation in Aipysurus eydouxii. This new characterisation was made following removal of A. mosaicus and is based on 37 specimens (19 adult males, 18 adult females) examined for this study including the type (see Table 2 and Appendix 2).

External morphological characters. One pre- and two postoculars on both sides in 35 specimens, 1-1/2-2 in two specimens, 1-1/1-2 in one specimen, 1-1/1-3 in one specimen. Six/six supralabials in 34 specimens, 7/6 in two specimens, $7 / 7$ in three specimens. First and second supralabials in contact with nasal in 38 specimens, first, second and third in one specimen. Second, third and fourth supralabial in contact with preocular in 22 specimens, second and third in 14 specimens, third and fourth in three specimens. Fourth supralabial in contact with eye in 32 specimens, third and fourth in six specimens, fourth and fifth in one specimen. Two anterior temporals on both sides in 28 specimens, $1 / 1$ in two specimens, $1 / 2$ in five specimens, $2 / 1$ in three specimens and 3/3 in one specimen. Six infralabials on both sides in 30 specimens, $7 / 7$ in two specimens, $6 / 7$ in three specimens, 5/6 in one specimen, 7/6 in three specimens. Sublinguals well developed and in contact with one another. First, second and third infralabial in contact with anterior pair of sublinguals in 34 specimens, first through fourth in three specimens, first and second in two specimens. Third and fourth infralabials touching posterior pair of sublinguals in 36 specimens, only fourth in one specimen, second and third in two specimens. Scale rows 15-17 on neck in males, 15-17 in females. Scale rows on body 16-17 in males, 17 in females. Fifteen scale rows ten ventrals before vent in males, 13-15 in females. Ventrals 127-143 in males, 136-149 in females, distinct throughout, about three to four times as broad as adjacent scales. Preanals enlarged and split up into two scales. Subcaudals 27-34 in males, 21-27 in females. Snout-vent length in largest male $49 \mathrm{~cm}$, tail length $9.5 \mathrm{~cm}$; largest female $80 \mathrm{~cm}$, tail $11.5 \mathrm{~cm}$.

Internal morphological characters: Tip of heart extending to ventral scale number 47-56 in males, 47-55 in females. \%VS-heart $34.5-40 \%$ in males, $33.1-39.6 \%$ in females. Anterior end of liver situated at ventral scale number 50-58 in males, 49-60 in females. \%VS-liver 36.0-42.2\% in males, $34.5-41.7 \%$ in females. Heart and 
liver separated by distance between 2-4 ventral scales in males, 1-4 in females. Compared to Aipysurus mosaicus, A. eydouxii has a smaller premaxilla, a larger maxilla, a triangular (rather than crescent-shaped) nasal, a straight (rather than anteriorly concave) frontoparietal suture, and caudal neural spines that lack dorsal expansions (Fig. 5).

Colouration: Head brown or pale brown above, same or paler below. Body usually cream, salmon or yellowish with brown to olive green cross-bands. Bands are broadest dorsally, narrowing on the sides and ventral surface. Scales between bands usually with dark margins. Number of bands on body 30-42 on males, 29-45 in females. Number of bands on tail 7-11 in males, 4-10 in females.

Distribution. Gulf of Thailand, Cambodia, Viet Nam, West Malaysia, Singapore and Java (Smith, 1926;1943; David \& Ineich, 1999). We also examined two specimens from New Guinea (Port Moresby: BMNH 1954.1.12.95 and "N. Riv. Bvj Bivukeil": RMNH 5784), but we did not find specimens from the area between the Sunda Shelf and New Guinea in the major museum collections (Berlin, Chicago, Leiden, London and Paris). Boulenger (1896) lists this species as also occurring in the Philippines but to the best of our knowledge no specimens have been collected to confirm this claim (Taylor, 1922; Herre, 1942; Dunson \& Minton, 1978; Alcala, 1986).

\section{Discussion}

Aipysurus mosaicus sp. nov. is a distinctive species of egg-eating sea snake from northern Australia and southern New Guinea. Previously considered an allopatric population of A. eydouxii (which is widespread on the Sunda Shelf), our molecular results show these taxa to be highly divergent sister lineages and our morphological analyses reveal a number of consistent differences relating to scalation, colour pattern, internal soft anatomy, and skeletal morphology. For all three molecular loci, the level of genetic divergence between Aipysurus mosaicus and A. eydouxii exceeds that found between sympatric species pairs of other sampled Aipysurus (duboisii+apraefrontalis, laevis+fuscus) and is in fact similar to the basal divergence between the latter four species. Further sampling is needed to clarify the geographic distribution of the two species, especially the extent of sympatry in New Guinea. We did not find specimens of either species from the area between the Sunda Shelf and New Guinea in the major museum collections (Berlin, Chicago, Leiden, London and Paris). However, we examined two independently collected specimens from southern Papua New Guinea that fit the morphology of A. eydouxii, suggesting this species' range might extend eastwards to overlap with A. mosaicus.

For the (few) variable nuclear sites across both loci, no haplotypes were shared between A. mosaicus and A. eydouxii; however, each of these species shared a haplotype with other Aipysurus species for one nuclear locus. Rather than indicating secondary introgression among A. mosaicus, A. eydouxii and their congeners, these shared nuclear haplotypes most probably reflect retained ancestral polymorphisms, given their incongruent distribution among species for the two loci and the absence of any shared haplotypes in the mt locus (which has features such as maternal inheritance and rapid evolution that generally reduce time to reciprocal monophyly after cladogenesis). The mt genetic distance between A. mosaicus and A. eydouxii (5.6\% pairwise for 16S, ND4 and cytb concatenated) is relatively high given the young age of sea snakes as a group (Sanders et al. 2008; Lukoschek et al. 2011). Applying the mean substitution rate of $2.7 \%$ (pairwise) per million years estimated for these concatenated genes using relaxed molecular clocks (see Sanders et al. 2008) would indicate a divergence time of approximately two million years ago.

Aipysurus mosaicus and A. eydouxii are primarily distributed on either side of the $2-3 \mathrm{~km}$ deep Timor Trench that separates the Sahul (Australian) and Sunda (Southeast Asian) continental shelves. This important marine biogeographic barrier has persisted throughout the glacial cycles of the last several million years (e.g. Hall 2009; Ovenden et al. 2009) and, given these species' preference for waters $<100 \mathrm{~m}$ deep, might be implicated in their initial isolation and subsequent divergence. Indeed, the Timor Trench probably plays a significant role in the delimitation of sea snake species boundaries: several species are restricted to either Australo-Papua or Southeast Asia (Heatwole 1999; IUCN Red List maps), and many species that span these regions show deep genetic structure suggesting higher levels of endemism than currently recognised (Sanders \& Rasmussen, unpublished data).

Despite being large, medically important snakes, hydrophiines are a conspicuously understudied group of marine vertebrates. Only eight sea snake species have been described in the last 30 years, most species' distributions are poorly understood (Rasmussen et al. 2011), and large areas in South and Southeast Asia remain mostly unsurveyed for sea snakes. The need for detailed taxonomic studies on sea snakes is especially urgent in light of the increasing pressure on shallow-marine ecosystems from fisheries and coastal development. 
We are grateful to the Indonesia Institute of Sciences (LIPI) for granting us permission to collect and export sea snake tissues from Indonesia. We thank the following museums for loan of specimens and access to their collections: AMS, MNHN, NHM (BMNH), QM, RMBR, RMNH, ZMH and ZMUC. Thanks also to eResearchSA and ARCS for access to supercomputer resources, Adelaide Microscopy for use of micro-CT scanning facilities, Ralph Foster for his valuable advice, and Paul Doughty and Mark Auliya for providing constructive reviews. This work was supported by an Australian Research Council (ARC) grant to KL Sanders and MSY LEE, and ARC, Australia and Pacific Science Foundation and University of Queensland funding to BC Fry.

\section{References}

Alcala, A.C. (1986) Amphibians and Reptiles. Guide to Philippine flora and fauna, 10, 1-195.

Arévalo, E., Davis, S.K. \& Sites, J. (1994) Mitochondrial DNA sequence divergence and phylogenetic relationships among eight chromosome races of the Sceloporus grammicus complex (Phrynosomatidae) in Central Mexico. Systematic Biology, 43, 387-418.

Bertozzi, T., Sanders, K.L., Sistrom, M.J. \& Gardner, M.G. Anonymous nuclear loci in non-model organisms: making the most of high throughput genome surveys. Bioinformatics doi:10.1093/bioinformatics/bts284.

Bleeker, P. (1858) 17. No title. Natuurwetenschappelijk Tijdschrift Voor Nederlandsch - Indië, 16, 49-50.

Boulenger, G. A. (1896) Catalogue of the snakes in the British Museum (Natural History). III Containing the Colubridae (Opistoglyphae and Proteroglyphae) Amblycephalidae and Viperidae. British Museum of Natural History, London, 727 pp.

Brown, J.M., Hedtke, S.M., Lemmon, A.R., Lemmon \& E.M. (2010) When Trees Grow Too Long: Investigating the Causes of Highly Inaccurate Bayesian Branch-Length Estimates. Systematic Biology, 59, 145-161. doi10.1093/sysbio/syp081.

Burbrink, F.T., Lawson, R. \& Slowinski, J.P. (2000) Mitochondrial DNA Phylogeography of the polytypic North American Rat Snake (Elaphe obsoleta): A critique of the subspecies concept. Evolution, 54, 2107-2118.

Cogger, H. (2007) Marine snakes. In Tzioumis, V. \& Keable, S. (Eds), Description of key species groups in the east marine region. Australian Museum, 80-94.

Cogger, H.G. (1975) Sea Snakes of Australia and New Guinea. In Dunson, W.A. (Ed.) The Biology of Sea Snakes. University Park Press, Baltimore London \& Tokyo, 59-139.

Cogger, H.G. (1992) Reptiles and Amphibians of Australia. Reed International Books, Chatswood New South Wales and Cornell University Press, New York., 775.

Cogger, H.G., Cameron, E.E. \& Cogger, H.M. (1983) Hydrophiidae. In Zoological catalogue of Australia. Amphibia and Reptilia. Government Publishing Service, Canberra: Australian, 241-256.

David, P. \& Ineich, I. (1999) Les serpents venimeux du monde: systématique et répartition. Dumerilia (Paris), 3, 3-499.

Drummond, A.J., Ashton, B., Buxton, S., Cheung, M., Cooper, A., Duran, C., Field, M., Heled, J., Kearse, M., Markowitz, S., Moir, R., Stones-Havas, S., Sturrock, S., Thierer, T. \& Wilson, A. (2010) Geneious v5.0.4 Available from http:// www.geneious.com.

Dunson, W.A. \& Minton, S.A. (1978) Diversity, Distribution, and Ecology of Philippine Marine Snakes (Reptilia, Serpentes). Journal of Herpetology, 12, 281-286.

Felsenstein, J. (1989) PHYLIP-Phylogeny Inference Package (Version 3.2). Cladistics, 5, 164-166.

Flower, S.S. (1899) Notes on a Second Collection of Reptiles made in the Malay Peninsula and Siam, from November 1896 to September 1898, with a List of the Species recorded from those Countries. Proceedings of the Zoological Society of London, 67, 600-697.

Fry, G.C., Milton, D.A. \& Wassenberg, T.J. (2001) The reproductive biology and diet of sea snake bycatch of prawn trawling in northern Australia: characteristics important for assessing the impacts on populations. Pacific conservation biology, 7 , $55-73$.

Glodek, G.S. \& Voris, H.K. (1982) Marine Snake Diets: Prey Composition, Diversity and Overlap. Copeia, 1982, 661-666.

Golay, P., Smith, H.M., Broadley, D.G., Dixon, J. R., McCarthy, C., Rage, J.C., Schätti, B. \& Toriba, M. (1993) Endoglyphs and other major venomous snakes of the world. A checklist. Herpetological Data Centre, Azemiops, Geneva, 478 pp.

Gray, J.E. (1849) Catalogue of the Specimens of Snakes in the Collection of the British Museum. Printed by order of the Trustees, $125 \mathrm{pp}$.

Greer, A.E. (1997) The biology and evolution of Australian snakes. Surrey Beatty and Sons Sydney New South Wales, Australia, $358 \mathrm{pp}$.

Günther, A.C.L.G. (1864) The reptiles of British India. Ray Society, London, 452 pp.

Hall, R. (2009). Southeast Asia's changing palaeogeography. Blumea, 54, 148-161.

Heatwole, H. (1975) Sea snakes of the Gulf of Carpentaria. In Dunson, W.A. (Ed), The Biology of Sea Snakes. London \& Tokyo, Baltimore, 145-149.

Heatwole, H. (1999) Sea Snakes. University of New South Wales Press, Sydney, 148 pp. 
Heatwole, H. \& Cogger, H.G. (1994) Sea snakes of Australia. In: Gopalakrishnakone, P. (Ed), Sea snake toxinology. Singapore University Press, Singapore, 167-205.

Heled, J. \& Drummond, A. (2010) Bayesian inference of species trees from multilocus data. Molecular Biology and Evolution, 27, 570-580.

Herre, A.W.C.T. (1942) Notes on Philippine Sea-Snakes. Copeia, 1942, 7-9.

Kass, R.E. \& Raftery, A.E. (1995) Bayes factors. Journal of the American Statistical Association, 90, 773-795.

Kharin, V.E. (1981) A review of sea snakes of the genus Aipysurus (Serpentes: Hydrophiidae). Zoologicheskii Zhurnal, 60, 257-254.

Kharin, V.E. (2005) A check-list of sea snakes (Serpentes: Laticaudidae, Hydrophiidae) of the World Ocean. Tinro, 140, 71-89.

Kharin, V. \& Hallermann, J. (2009) Annotated catalogue of sea kraits (Laticaudidae) and sea snakes (Hydrophiidae) of the herpetological collection of the Zoological Museum, University of Hamburg. obiliteilungen aus dem Hamburgischen zoologische Museum und Institutiös], 106, 51-67.

Kocher, T.D., Thomas, W.K., Meyer, A., Edwards, S.V., Paabo, S., Villablanca, F.X. \& Wilson, A.C. (1989) Dynamics of mitochondrial DNA evolution in animals: amplification and sequencing with conserved primers. Proceedings of the National Academy of Sciences of the United States of America, 86, 6196-6200.

Krefft, G., Scott, H. \& Forde, H. (1869) The Snakes of Australia: An Illustrated and Descriptive Catalogue of All the Known Species. T. Richards, Government Printer, $100 \mathrm{pp}$.

Lemen, C.A. \& Voris, H.K. (1981) A Comparison of Reproductive Strategies Among Marine Snakes. The Journal of Animal Ecology, 50, 89-101.

Leviton, A.E., Gibbs, R.H., Heal, E. \& Dawson, C.E. (1985) Standards in Herpetology and Ichthyology Part I. Standard Symbolic Codes for Institutional Rescource Collections in Herpetology and Ichthyology. Copeia, 1985, 802-832.

Li, M., Fry, B.G. \& Kini, R.M. (2005a) Eggs-Only Diet: Its Implications for the Toxin Profile Changes and Ecology of the Marbled Sea Snake (Aipysurus eydouxii). Journal of Molecular Evolution, 60, 81-89.

Li, M., Fry, B.G. \& Kini, R.M. (2005b) Putting the Brakes on Snake Venom Evolution: The Unique Molecular Evolutionary Patterns of Aipysurus eydouxii (Marbled Sea Snake) Phospholipase A2 Toxins. Molecular Biology and Evolution, 22, 934-941.

Librado, P. \& Rozas, J. (2009) DnaSP v5: A software for comprehensive analysis of DNA polymorphism data. Bioinformatics 25, 1451-1452 doi: 10.1093/bioinformatics/btp187.

Lim, B.L. \& Sawai, Y. (1976) In Ohsaka, A., Hayashi, K. \& Sawai, Y. (Eds), Ecology and distribution of some sea snakes in Peninsular Malaysia. Animal, plant and microbial toxins, New York, 515-520.

Limpus, C.J. (1975) In Dunson, W.A. (Ed), Coastal sea snakes of subtropical Queensland waters (230 to 280 south latitude). The Biology of Sea Snakes. University Park Press, London \& Tokyo, 174-182.

Lukoschek, V. \& Keogh, J.S. (2006) Molecular phylogeny of sea snakes reveals a rapidly diverged adaptive radiation. Biological Journal of the Linnean Society, 89, 523-539.

Lukoschek, V., Keogh, J.S. \& Avise, J.C. (2011) Evaluating Fossil Calibrations for Dating Phylogenies in Light of Rates of Molecular Evolution: A Comparison of Three Approaches. Systematic Biology, doi: 10.1093/sysbio/syr075.

Masters, B.C., Fan, V. \& Ross, H.A. (2011) Species delimitation-a geneious plugin for the exploration of species boundaries. Molecular Ecology Resources, 11, 154-157

MacPherson, J. (1933) Freshwater Snakes and Sea Snakes. The Australasian Nurses Journal, 31, 100-103.

McCarthy, C.J. \& Warrell, D. (1991) A collection of sea snakes from Thailand with new records of Hydrophis belcheri (Gray). Bulletin of Natural History Museum (zoology), London, 57, 161-166.

Minton, S.A. (1975) Geographic distribution of sea snakes. In Dunson, W.A. (Ed), The Biology of Sea Snakes. London \& Tokyo, Baltimore, 21-31.

Murphy, J.C., Cox, M.J. \& Voris, H.K. (1999) A key to the sea snakes in the Gulf of Thailand. Natural History Bulletin of the Siam Society, 47, 95-108.

Nylander, J.A.A. (2004) MRMODELTEST v2.2. Program Distributed by the Author. Evolutionary Biology Centre, Uppsala University.

Ovenden, J.R., Kashiwagi, T., Broderick, D., Giles, J. \& Salini, J. (2009) The extent of population genetic subdivision differs among four co-distributed shark species in the Indo-Australian archipelago. BMC Evolutionary Biology, 9(1), 40.

Porter, R., Irwin, S., Irwin, T. \& Rodrigues, K. (1997) Records of marine snake species from The Hey-embley and Mission Rivers far North Queensland. Herpetofauna (Sydney), 27, 2-7.

Rambaut A. \& Drummond, A.J. (2007) Tracer v1.4, Available from http://beast.bio.ed.ac.uk/Tracer

Rasmussen, A.R. (1989) An analysis of Hydrophis ornatus (Gray), H. lamberti Smith, and H. inornatus (Gray)(Hydrophiidae, Serpentes) based on samples from various localities, with remarks on feeding and breeding biology of H. ornatus. Amphibia-Reptilia, 10, 397-417.

Rasmussen, A.R. (1993) The status of the Persian Gulf Sea Snake Hydrophis lapemoides (Gray, 1849) (Serpentes, Hydrophiidae). Bulletin of Natural History Museum (zoology), London, 59, 97-105.

Rasmussen, A.R. (1997) Systematics of sea snakes: A critical review. Symposium of the Zoological Society of London, 70 , 15-30.

Rasmussen, A.R. (2002) Phylogenetic analysis of the "true" aquatic elapid snakes Hydrophiinae (sensu Smith et al. 1977) indicating two independent radiations into water. Steenstrupia, 27, 47-63. 
Rasmussen, A.R., Murphy, J.C., Ompi, M., Gibbons, J.W. \& Uetz, P. (2011) Marine Reptiles. PLos One, 6, 1-12.

Redfield, J.A., Holmes, J.C. \& Holms, R.D. (1978) Sea snakes of the eastern Gulf of Carpentaria. Australian Journal of Marine and Freshwater Research, 29, 325-334.

Ronquist, F. \& Huelsenbeck, J.P. (2003) MRBAYES 3: Bayesian phylogenetic inference under mixed models. Bioinformatics, 19, 1572-1574. doi:10.1093/bioinformatics/btg180

Sanders, K.L., Lee, M.S.Y., Leys, R., Foster, R. \& Keogh, J.S. (2008) Molecular phylogeny and divergence dates for Australasian elapids and sea snakes (hydrophiinae): evidence from seven genes for rapid evolutionary radiations. Journal of Evolutionary Biology, 21, 682-695.

Sanders, K.L., Mumpuni \& Lee, M.S.Y. (2010) Uncoupling ecological innovation and speciation in sea snakes (Elapidae, Hydrophiinae, Hydrophiini). Journal of Evolutionary Biology, 23, 2685-2695.

Schmidt, P. (1852) Beiträge zur ferneren Kenntniss der Meerschlangen. Abhandlungen aus dem Gebiete der Naturwissenschaften, 2, 69-86.

Smith, L.A. (1974) The sea snakes of Western Australia (Serpentes: Elapidae, Hydrophiinae), with a description of a new subspecies. Record of the Western Australian Museum, 3, 93-110.

Smith, M.A. (1926) Monograph of the sea-snakes (Hydrophiidae). Printed by order of the Trustees of the British museum (Natural History) London, $130 \mathrm{pp}$.

Smith, M.A. (1943) The fauna of British India, Ceylon and Burma. Reptilia and Amphibia Taylor \& Francis, London, 1-583 pp.

Stephens, M. \& Donnelly, P. (2003) A comparison of Bayesian methods for haplotype reconstruction from population genotype data. American Journal of Human Genetics, 73, 1162-1169.

Stephens, M., Smith, N. \& Donnelly, P. (2001) A new statistical method for haplotype reconstruction from population data. American Journal of Human Genetics, 68, 978-989.

Stuebing, R.B. (1991). A checklist of the snakes of Borneo. Raffles Bulletin of Zoology, 39, 323-362.

Swofford, D.L. (2002) PAUP* 4.0: phylogenetic analysis using parsimony (*and other methods). Beta version 4.0b4a. Sinauer Associates, Sunderland, MA

Taylor, E.H. (1922) The snakes of the Philippine Islands. Bureau of Printing, Manila, 555 pp.

Taylor, E.H. (1965) The serpentes of Thailand and adjacent waters. University of Kansas Science Bulletin, 9, 609-1096.

Thomas, R.A. (1976) Dorsal scale row formulae in snakes. Copeia, 1976, 837-841.

Voris, H.K. (1966) Fish Eggs as the Apparent Sole Food Item for a Genus of Sea Snake, Emydocephalus (Krefft). Ecology, 47, 152-154.

Voris, H.K. (1977) A phylogeny of the sea snakes (Hydrophiidae). Fieldiana Zoology, 70, 79-166.

Wall, F. (1909) A monograph of the sea snakes. Memoirs of the Asiatic Society of Bengal, 2, 169-251.

Ward, T.M. (2000) Factors affecting the catch rates and relative abundance of sea snakes in the by-catch of trawlers targeting tiger and endeavour prawns on the northern Australian continental shelf. Marine and Freshwater Research, 51, $155-164$.

Wells, R.W. (2007) Some taxonomic and nomenclatural considerations on the class Reptilia in Australia. The sea snakes of Australia. An introduction to the members of the families Hydrophiidae and Laticaudidae in Australia, with a new familial and generic arrangement. Australian Biodiversity Record, 8, 1-124.

Wells, R.W. \& Wellington, C.R. (1983) A synopsis of the class Reptilia in Australia. Australian. Journal of Herpetology, 1, 73-129.

Zwickl, D.J. (2006) Genetic algorithm approaches for the phylogenetic analysis of large biological sequence datasets under the maximum likelihood criterion. Ph.D., University of Texas at Austin. 
APPENDIX 1. Locality information, voucher and GenBank accession numbers for specimens used in phylogenetic analyses.

\begin{tabular}{|c|c|c|c|c|c|c|c|c|}
\hline \multirow[t]{2}{*}{ Genus } & \multirow[t]{2}{*}{ Species } & \multirow{2}{*}{$\begin{array}{l}\text { Museum/Field } \\
\#\end{array}$} & \multirow[t]{2}{*}{ Collection locality } & \multicolumn{5}{|c|}{ GenBank accession numbers } \\
\hline & & & & cytb & ND4 & $16 \mathrm{~S}$ & G1888 & G1894 \\
\hline \multirow[t]{24}{*}{ Aipysurus } & \multirow[t]{3}{*}{$\begin{array}{l}\text { apraefronta- } \\
\text { lis }\end{array}$} & WAM154750 & $\begin{array}{l}\text { Bundegi Reef, West } \\
\text { ern Australia }\end{array}$ & - & JX423410 & JX423421 & $\begin{array}{l}\mathrm{JX} 423464 \\
\mathrm{JX} 423465\end{array}$ & JX423438 \\
\hline & & WAM157818 & $\begin{array}{l}\text { Exmouth, Western } \\
\text { Australia }\end{array}$ & JX002974 & JX002981 & JX002987 & $\begin{array}{l}\text { JX423466 } \\
\text { JX423467 }\end{array}$ & JX423439 \\
\hline & & MGAa41201 & $\begin{array}{l}\text { Northern Territory, } \\
\text { Australia }\end{array}$ & - & - & JX423420 & - & - \\
\hline & \multirow[t]{3}{*}{ duboisii } & ABTC29025 & $\begin{array}{l}\text { Hibernia Reef, West } \\
\text { ern Australia }\end{array}$ & JX423392 & JX423411 & JX423422 & JX423468 & $\begin{array}{l}\text { JX423440 } \\
\text { JX423441 }\end{array}$ \\
\hline & & ABTC29029 & $\begin{array}{l}\text { Hibernia Reef, West } \\
\text { ern Australia }\end{array}$ & - & JX423412 & - & - & - \\
\hline & & ABTC29031 & $\begin{array}{l}\text { Hibernia Reef, West } \\
\text { ern Australia }\end{array}$ & JX423393 & - & JX423423 & JX423469 & JX423442 \\
\hline & \multirow[t]{4}{*}{ mosaicus } & ABTC55522 & $\begin{array}{l}\text { Gulf of Carpentaria, } \\
\text { Australia }\end{array}$ & - & JX423416 & - & JX423470 & JX423443 \\
\hline & & BGF04498 & $\begin{array}{l}\text { Weipa, Queensland, } \\
\text { Australia }\end{array}$ & JX423399 & JX423417 & JX423426 & JX423471 & JX423444 \\
\hline & & BGF04678 & $\begin{array}{l}\text { Weipa, Queensland, } \\
\text { Australia }\end{array}$ & JX423400 & - & & JX423472 & JX423445 \\
\hline & & BGF04697 & $\begin{array}{l}\text { Weipa, Queensland, } \\
\text { Australia }\end{array}$ & - & - & JX423427 & JX423473 & JX423446 \\
\hline & \multirow[t]{4}{*}{ fuscus } & MGAfu1 & $\begin{array}{l}\text { Northern Territory, } \\
\text { Australia }\end{array}$ & JX423402 & - & JX423430 & JX423480 & - \\
\hline & & MGAfu 2 & $\begin{array}{l}\text { Northern Territory, } \\
\text { Australia }\end{array}$ & JX423403 & - & JX423431 & JX423481 & - \\
\hline & & MGAfu 3 & $\begin{array}{l}\text { Northern Territory, } \\
\text { Australia }\end{array}$ & JX423404 & - & JX423432 & JX423483 & - \\
\hline & & MGAfu 10 & $\begin{array}{l}\text { Northern Territory, } \\
\text { Australia }\end{array}$ & JX423401 & - & JX423429 & JX423482 & - \\
\hline & \multirow[t]{4}{*}{ laevis } & MGAl 3 & $\begin{array}{l}\text { Northern Territory, } \\
\text { Australia }\end{array}$ & JX423405 & - & JX423433 & JX423486 & JX423458 \\
\hline & & MGAl 4 & $\begin{array}{l}\text { Northern Territory, } \\
\text { Australia }\end{array}$ & JX423406 & - & JX423434 & JX423487 & JX423459 \\
\hline & & ABTC29023 & $\begin{array}{l}\text { Cartier Islet, Western } \\
\text { Australia }\end{array}$ & - & JX423418 & - & JX423484 & JX423455 \\
\hline & & ABTC29024 & $\begin{array}{l}\text { Cartier Islet, Western } \\
\text { Australia }\end{array}$ & - & JX423419 & - & JX423485 & $\begin{array}{l}\text { JX423456 } \\
\text { JX423457 }\end{array}$ \\
\hline & \multirow[t]{6}{*}{ eydouxii } & $\begin{array}{l}\text { MZB Ophi } \\
4178\end{array}$ & $\begin{array}{l}\text { Pasuruan, East Java, } \\
\text { Indonesia }\end{array}$ & JX002975 & JX002982 & JX002988 & JX423474 & JX423447 \\
\hline & & $\begin{array}{l}\text { MZB Ophi } \\
4181\end{array}$ & $\begin{array}{l}\text { Pasuruan, East Java, } \\
\text { Indonesia }\end{array}$ & JX423395 & - & JX423424 & JX423475 & JX423448 \\
\hline & & $\begin{array}{l}\text { MZB Ophi } \\
4184\end{array}$ & $\begin{array}{l}\text { Pasuruan, East Java, } \\
\text { Indonesia }\end{array}$ & JX423396 & JX423413 & - & JX423476 & JX423449 \\
\hline & & $\begin{array}{l}\text { MZB Ophi } \\
4185\end{array}$ & $\begin{array}{l}\text { Pasuruan, East Java, } \\
\text { Indonesia }\end{array}$ & JX423397 & JX423414 & - & JX423477 & $\begin{array}{l}\text { JX423450 } \\
\text { JX423451 }\end{array}$ \\
\hline & & $\begin{array}{l}\text { MZB Ophi } \\
4186\end{array}$ & $\begin{array}{l}\text { Pasuruan, East Java, } \\
\text { Indonesia }\end{array}$ & JX423398 & - & - & JX423478 & JX423452 \\
\hline & & $\begin{array}{l}\text { MZB Ophi } \\
4187\end{array}$ & $\begin{array}{l}\text { Pasuruan, East Java, } \\
\text { Indonesia }\end{array}$ & - & JX423415 & JX423425 & JX423479 & $\begin{array}{l}\text { JX423453 } \\
\text { JX423454 }\end{array}$ \\
\hline \multirow[t]{4}{*}{$\begin{array}{l}\text { Emydo- } \\
\text { cephalus }\end{array}$} & \multirow[t]{4}{*}{ annulatus } & ABTC29030 & $\begin{array}{l}\text { Hibernia Reef, West } \\
\text { ern Australia }\end{array}$ & EU547087 & EU547038 & EU547185 & JX423488 & JX423460 \\
\hline & & MGEa2 & $\begin{array}{l}\text { Northern Territory, } \\
\text { Australia }\end{array}$ & JX423408 & - & JX423436 & JX423490 & JX423462 \\
\hline & & MGEa3 & $\begin{array}{l}\text { Northern Territory, } \\
\text { Australia }\end{array}$ & JX423409 & - & JX423437 & JX423491 & JX423463 \\
\hline & & MGEa111201 & $\begin{array}{l}\text { Northern Territory, } \\
\text { Australia }\end{array}$ & JX423407 & - & JX423435 & JX423489 & JX423461 \\
\hline \multirow[t]{2}{*}{ Hydrophis } & \multirow[t]{2}{*}{ caerulescens } & $\begin{array}{l}\text { MZB } \\
4141\end{array}$ & $\begin{array}{l}\text { Pasuruan, East Java, } \\
\text { Indonesia }\end{array}$ & - & - & - & JQ217164 & $\begin{array}{l}\text { JQ217186 } \\
\text { JQ217187 }\end{array}$ \\
\hline & & $\begin{array}{l}\text { MZB Ophi } \\
4145\end{array}$ & $\begin{array}{l}\text { Pasuruan, East Java, } \\
\text { Indonesia }\end{array}$ & JG217208 & JQ217154 & JG217218 & - & - \\
\hline
\end{tabular}




\section{APPENDIX 2}

Specimens examined for morphological analysis. Locality information is provided for Aipysurus eydouxii and A. mosaicus sp. nov where available.

Aipysurus apraefrontalis: AMS R 44616, 44878. BMNH 19461.1.94-95 (types), 1926.5.28.21-22, 1927.9.28.4.

Aipysurus duboisii: AMS R 3346, 8641, 14427, 15088, 17743, 20779, 37139, 40497, 41005, 41057, 41059-060, 41062-065, 41520, 42024, 42102, 44398-399, 44401-402, 44404, 44407-408, 44410-413, 44430, 44459, 44496, 44502, 44552, 44611, $44617,44631,44861,44863,44895,44903,95003,95185,107755,109667,110307-309$. BMNH 58.10.95.12, 64.9.19.14, 1926.5.28.25-27, 1926.2.16.12.

Aipysurus eydouxii: Java, Indonesia: BMNH (18)91.6.17.4, (18)96.6.25.48, 1926.11.1.19 (two specimens), 1946.1.7.1 (type of margaritophorus 63.12.4.6); Singapore: (18)97.2.3.19; Gulf of Thailand, Thailand: 1921.2.11.139-40; Sai Buri, Thailand: 1987.37; Hua Hin, Vietnam: 1926.5.28.15; Indian Ocean: 1946.1.6.86 (type); Port Moresby, Papua New Guinea: 1954.1.12.95. MNHN 3971, 7704. South China Sea: RMBR 2028. RMNH 1474, 4601A-B, 4659, 4660, 4779, 5784, 8017, 12622, 25845-46, 36317-19. Southern Vietnam: ZMH 3435, 3437, 3440, 3588, 5388-90, 5889. The types of A. anguillaeformis and A. muraenaeformis from Naturhistorisches Museum Hamburg were destroyed during the Second World War (Kharin \& Hallermann, 2009).

Aipysurus foliosquama: AMS R 37143, 40488-489, 40496, 41516, 41526, 41537, 44456, 44576, 44592, 44597, 44619, 44872, 44890, 44896, 44899, 44902, 44906, 104810. BMNH 1946.1.1.96 (syntype), 1946.1.1.86 (syntype) 1946.1.1.87 (syntype), 1946.1.1.88 (syntype), 1926.5.23-25. RMNH 6430 (paratype).

Aipysurus fuscus: AMS R 40481-482, 40487, 40498, 41055, 41533-535, 41538, 44441, 44586, 44603, 44869, 44879, 44880, 44887, 44893, 44916, 45052. BMNH 1926.2.16.1-4, 1926.5.28.16-20 ZMB 2824 (type).

Aipysurus laevis: AMS R 3643, 7183, 7740, 8642, 11327, 18254, 19137, 30347, 33208, 33247, 33276, 33354-355, 33272, 37138, 40490-491, 40501, 41007, 41009-012, 41014, 41035, 41035, 41048, 41049-052, 41507, 41514, 41523-525, 41527529, 41539, 42038, 42698-699, 44627. ZMB 7681. MNHN 639. RMNH 1495

Aipysurus mosaicus sp. nov.: Arafura Sea off Coburg Peninsula, Northern Territory, Australia: AMS R 33244, 33246, 33249 , 33251, 33278; Townsville District, Queensland Australia: AMS R 41030-033; Torres Strait in the vicinity of Thursday Island, Queensland Australia: AMS R 93055, Gulf of Carpentaria, Queensland, Australia: SAMA 23493 (paratype), AMS R 95083, 95099, 95103, 95109. Coral Sea between Queensland and New Caledonia: BMNH 1928.4.11.3-5. Weipa, Gulf of Carpentaria, Queensland Australia: SAMA 65222 (holotype), AMS R 17623. No locality information within Australia: AMS R 144775, AMS R 42034, 44524, 44969, 44975, 44984, 44989, QM J 80567.

Aipysurus pooleorum: Data from Smith (1974)

Aipysurus tenuis: NHRM 2400.1-3. 